
A
$\mathbf{R}$
$\mathbf{T}$
Y
$\mathbf{K}$
$\mathbf{U}$
$\mathbf{L}$

JANUSZ KRĘCIDŁO MS

Studia Theologica Varsaviensia
UKSW
$1 / 2016$

\title{
ANTROPOLOGICZNA KATEGORIA WSTYDU I JEJ NOŚNOŚĆ W PISMACH NOWEGO TESTAMENTU
}

Artykuł składał będzie się z dwóch części. W pierwszej z nich chcemy zająć się zagadnieniami związanymi z wyjaśnieniem antropologicznej kategorii wstydu w kulturze śródziemnomorskiej czasów Nowego Testamentu. W drugiej zaś, ukażemy na kilku wybranych przykładach, w jaki sposób owa koncepcja znajduje odzwierciedlenie w pismach Nowego Testamentu.

\section{WSTYD JAKO ANTYWARTOŚĆ \\ W KULTURZE ŚRÓDZIEMNOMORSKIEJ CZASÓW NOWEGO TESTAMENTU I JEGO POWIĄZANIE Z HONOREM}

Rzeczywistość określana w języku polskim jako „wstyd” rozumiana jest dziś powszechnie jako rodzaj emocji związanych z przykrymi myślami o własnej ułomności. Psychologowie dzielą doświadczenia wstydu na zdrowe i toksyczne. Zdrowy wstyd stoi na straży ludzkiej godności. Toksyczny wstyd zaś wyzwala w człowieku poczucie własnej niedoskonałości, bezwartościowości i ułomności ${ }^{1}$. Nie takie było rozumienie wstydu w starożytnej kolektywistycznej kulturze świata śródziemnomorskiego. Nie funkcjonował on jako indywidualna cecha człowieka i jako pojęcie autonomiczne, lecz był antytetycznie powiązany z rzeczywistością honoru, rozumianego

${ }^{1}$ Zjawisko to opisuje dobrze np. A. D o d z i u k, Wstyd. Jak lepiej go rozumieć i nie pozwolić, żeby zatruwal nam życie?, Warszawa 1999. 
jako: sława, chwała, godność, reputacja, wartość człowieka w publicznej ocenie. Wstyd stanowił zatem w tamtej kulturze antytezę wymienionych wartości. Wstyd w rozumieniu ludzi współczesnych Jezusowi to: niesława, niegodność, hańba, brak reputacji, nieposiadanie w sobie wartości społecznie cenionych.

Wstyd nie był pojmowany w kategoriach moralnego poczucia winy, jak to jest postrzegane we współczesnej zachodniej kulturze. Poczucie wstydu we współczesnym rozumieniu to wewnętrzny głos sumienia człowieka wzbudzający w nim poczucie winy z powodu nagannego postępowania. Natomiast w kolektywistycznej kulturze śródziemnomorskiej, ,sumieniem” człowieka była grupa społeczna, która oceniała jego postępowanie, jako godne pochwały lub naganne. Wstyd bądź honor nie były odnoszone do wewnętrznego poczucia człowieka, lecz stanowiły domeną publicznego arbitrażu.

Ze względu na podane powyżej motywy, rzeczywistość wstydu analizować będziemy na tle pojmowania honoru. W starożytnej cywilizacji śródziemnomorskiej honor uznawany był za najważniejszą wartość w życiu człowieka². Rozumiano go jako reputację - posiadaną przez każdego - w publicznej ocenie. Przez ludzi szlachetnych honor był ceniony bardziej niż życie. Honor przypisywany człowiekowi przez innych członków społeczeństwa determinował wszystkie sfery jego życia. Natomiast pozbawienie kogoś należnego mu honoru (czyli wstyd) uważane było za życiową katastrofę, nie tylko w aspekcie indywidualnym, lecz także oznaczało utratę prestiżu przez całą jego rodzinę ${ }^{3}$.

Analogicznie do honoru, również wstyd zawierał w sobie dwa podstawowe elementy: wstyd dziedziczony przez przyjście na świat w rodzinie, która nie była darzona społecznym szacunkiem oraz

2 Antropolodzy kultury zgodnie określają honor jako pivotal value tzn. osiowa/ centralna wartość w kulturze śródziemnomorskiej. Zob. szerzej np. B. J. M a 1 i n a, The New Testament World. Insights from Cultural Anthropology, Louisville 2001, s. 27-57.

${ }^{3}$ Zob. R. L. Roh rbaugh, Honor. Core Value in the Biblical World, w: D. N e u f e ld, R. E. D e M a r i s (red.), Understanding the Social World of the New Testament, London 2010, s. 110. 
wstyd nabywany przez człowieka poprzez niechwalebne czyny, zasługujące na społeczne potępienie. Dziedziczony wstyd, wynikający z przyjścia na świat w rodzinie o niskim statusie społecznym mógł być zmazany jeżeli ktoś został adoptowany przez rodzinę o wyższym statusie społecznym. Świadomość posiadania przez człowieka niskiego statusu społecznego (wstydu) powinna skłaniać go do okazywania czci (honoru) ludziom posiadającym wyższy od niego status.

Ludzie, którzy wywodzili się z najniższych warstw społecznych, byli niejako $\mathrm{z}$ definicji pozbawieni honoru rozumianego jako społeczny prestiż. Ich najbardziej nawet chwalebne czyny mogły jedynie w niewielkim stopniu przydać im honoru. Niektóre zawody były z definicji uważane za wstydliwe, a ludzie uprawiający je byli nieodwołalnie uważani za godnych pogardy/wstydu. Do tych zawodów zaliczano m.in.: prostytutki, marynarzy, oberżystów, celników. Uważano, że uprawiane przez nich profesje pozbawiają ich wrażliwości na sprawy honoru i sprawiają, że chronicznie trwają w stanie hańby. Panowało powszechne przekonanie, że ludzie tych zawodów nie byli w stanie respektować norm honoru przyjętych powszechnie w społeczności, w której żyli. W związku z tym stanowili zagrożenie dla społecznej stabilizacji ${ }^{4}$.

Wstyd, prócz charakteryzowanego tutaj negatywnego wymiaru, mógł być wszakże postrzegany jako pozytywna cecha. Przykład tego znajdujemy np. u Arystotelesa, wg którego posiadać wstyd to troszczyć się o własny honor i mieć świadomość jakie działania mogą doprowadzić człowieka do jego utraty ${ }^{5}$. Lęk przed wstydem był porównywany przez Stagirytę do lęku przed śmiercią. Twierdził on, że wstyd to cecha ludzi młodych, którzy nie wiedzą jeszcze jak należy zachowywać się w różnych życiowych sytuacjach.

Po tej linii szedł również Plutarch, gdy przekonywał, że poczucie wstydu jest cechą człowieka mądrego, gdyż pozwala ono człowiekowi

${ }^{4}$ Tamże, s. 113.

5 A ry s t o t e le s, Etyka nikomachejska, (ttum. D. Gromska), Warszawa 2007, 4.9. 
rozeznać co jest honorowe, a co nie ${ }^{6}$. $\mathrm{Z}$ tego właśnie powodu wstyd był w kulturze śródziemnomorskiej identyfikowany jako cecha kobiet, a kobiety w związku $\mathrm{z}$ tym stereotypowo oceniane były jako mądre. Wiązało się to również z ograniczeniem aktywności życiowej kobiet do przestrzeni prywatnej domostwa, ze względu na czyhające w przestrzeni publicznej zagrożenia utraty ich honoru. Powściągliwość kobiet i ich wycofanie do przestrzeni prywatnej oceniane jako mądre, wynikało z niebezpieczeństwa utraty honoru własnego i rodziny. Mądrość kobiet, wynikająca z posiadanego przez nie naturalnego poczucia wstydu, postrzegana była jako ważna cecha sprzyjająca właściwemu wychowaniu dzieci do powściągliwości. Plutarch twierdził, że najlepszym nauczycielem i wychowawcą jest filozofia, dzięki której młody człowiek rozpoznaje, co jest godne czci a co zawstydzające?.

W opisanych powyżej sytuacjach wstyd rozumiany jest jako pozytywna cecha ludzkiej natury, polegająca na posiadaniu potrzebnej wrażliwości, warunkującą mądrość, pozwalającą człowiekowi godnie zachowywać się w przestrzeni publicznej. Wyjaśniliśmy zagadnienia związane ze wstydem dziedziczonym i nabywanym. Nim przejdziemy do ukazania na kilku przykładach w jaki sposób autorzy Nowego Testamentu odwołują się do kategorii wstydu i honoru, należy wyeksponować jeszcze kilka szczegółów.

Kultura starożytnego świata śródziemnomorskiego uznawana jest za kulturę agonistyczną. Myślenie typowe dla tej kultury wynika z powszechnego przekonania, że liczba dóbr materialnych i duchowych, które człowiek może posiąść, jest ograniczona. O honor trzeba zatem walczyć z innymi. Pozbawienie kogoś innego tego dobra, czyli wykazanie jego niesławy sprawia, że honor człowieka może się pomnożyć. Pozyskiwanie honoru odbywało się na drodze codziennych konfrontacji określanych jako „gra o honor” na zasadzie „wyzwanie - odpowiedź”. Pretendent do pozyskania honoru

\footnotetext{
${ }^{6} \mathrm{P} 1 \mathrm{u}$ t a r c h, Moralia. Wybór pism filozoficzno-moralnych, (tłum. Z. Abramowiczówna), Wrocław 2005, 6.51.

7 Tamże, 1.7.10.
} 
kierował w przestrzeni publicznej, wobec świadków, do adwersarza fizyczne (np. uderzenie) lub słowne wyzwanie, które ten powinien przyjąć i zripostować. Proces ten mógł powtarzać się kilkakrotnie i musiał kończyć się werdyktem obserwatorów, którzy decydowali o tym, która ze stron pozyskała honor, a która została go pozbawiona czyli zawstydzona. Zdobyty honor stawał się udziałem całej rodziny zwycięzcy, a niesława dotykała również całej rodziny przegranego. Należy tu jeszcze dodać, że do takich konfrontacji stawać mogli jedynie ludzie o równym lub zbliżonym statusie społecznym.

\section{PRZYKLADY ODWOLYWANIA SIE PRZEZ AUTORÓW NOWEGO TESTAMENTU DO KATEGORII HONORU I WSTYDU}

W tle licznych perykop Pisma Świętego pobrzmiewa mniej lub bardziej świadome odwoływanie się autorów do kluczowej wartości honoru i jego zaprzeczenia, czyli wstydu. Aby ukazać ten mechanizm przedstawimy trzy reprezentatywne przykłady z Nowego Testamentu.

\subsection{Wyjątkowy honor dziedziczony Jezusa pomimo wstydu pochodzenia z nizin społecznych $($ Mt 1,1-17)}

Jak sygnalizowaliśmy powyżej, honor i wstyd posiadały dwa komponenty. Osoby, które rodziły się w rodzinach o wysokim statusie społecznym dziedziczyły po przodkach wysoki honor. Ci zaś, którzy przychodzili na świat w rodzinach ze społecznego marginesu, dziedziczyli wstyd. Poza tym każdy, niezależnie od dziedziczonego honoru lub wstydu, pozyskiwał honor bądź niesławę w codziennych społecznych interakcjach z innymi.

Pierwsze dwa rozdziały Ewangelii wg św. Mateusza i Łukasza noszą nazwę Ewangelii dzieciństwa. Tytuł ten jest trochę mylący, gdyż w istocie zarówno Pierwsza jak i Trzecia Ewangelia zawierają $\mathrm{w}$ dwóch pierwszych rozdziałach w znamienitej większości narracje o okolicznościach związanych z narodzeniem Jezusa, a nie 
z pierwszymi latami jego życia ${ }^{8}$. Mateusz rozpoczyna swoją Ewangelię od rodowodu Jezusa (1,1-17). Wiadomo, że rodowody w kulturze śródziemnomorskiej (w tym także w Starym Testamencie) powstawały dla ściśle określonych celów pragmatycznych. Sporządzano je „dla celów wewnątrzrodzinnych, polityczno-prawnych, ekonomicznych oraz religijnych"9. Tworzono je dla udokumentowania wobec innych swojej wysokiej pozycji społecznej poprzez powoływanie się na fakt pochodzenia od cenionych przodków. Im genealogia sięgała bardziej odległych czasów, a ten, kto się nią legitymował potrafił wskazać bardziej szanowanych antenatów, tym większy przysługiwał mu honor dziedziczony.

Jeśli chodzi o rodowód zamieszczony w Mt 1,1-17, to już z samego faktu podania go na samym początku Ewangelii wynika, że autor chciał, by był to dla czytelnika podstawowy punkt odniesienia w ocenie honoru Jezusa. Już w 1,1 Jezus jest przedstawiony jako Chrystus czyli Boży Pomazaniec - Mesjasz oraz potomek Abrahama i Dawida. Następnie zaś Mateusz rozpisuje ów rodowód w szczegółach, podając najznamienitszych, zasadniczo męskich przodków Jezusa, w zestawach po czternaście pokoleń ${ }^{10}$. Ostatnie zdanie tej perykopy $(1,17)$ dobrze oddaje strukturę zamierzoną przez autora: „Tak więc od Abrahama do Dawida jest w sumie czternaście pokoleń; od Dawida do przesiedlenia babilońskiego czternaście pokoleń; od przesiedlenia babilońskiego do Chrystusa czternaście pokoleń".

Nie ma tu miejsca na wchodzenie w cechy honoru wszystkich znajdujących się w tym rodowodzie postaci (ale i wstydu, bo nie wszystkie zamieszczone w rodowodzie osoby są bez skazy). Warto

${ }_{8}^{8}$ Jedynym fragmentem owych Ewangelii dzieciństwa, który rzeczywiście traktuje o dzieciństwie Jezusa jest $Ł k$ 2,41-52, gdzie jest mowa o pobycie dwunastoletniego Jezusa w jerozolimskiej świątyni, podsumowana komentarzem Łukasza: „Potem poszedł z nimi i wrócił do Nazaretu; i był im poddany (...). Jezus zaś czynił postępy w mądrości, w latach i w łasce u Boga i u ludzi” (2,51-52).

9 Zob. J. K r ę c i d ł o, Honor i wstyd winterpretacji Ewangelii. Szkice z egzegezy antropologicznokulturowej, Warszawa 2013, s. 86.

${ }_{10} \mathrm{~W}$ rodowodzie tym pojawiają się również cztery kobiece antenatki Jezusa: Tamar $(1,3)$, Rachab $(1,5)$, Rut $(1,5)$ i Batszeba $(1,6)$. 
spojrzeć jednak na tych, które w opinii Mateusza zasługują na specjalne wyróżnienie: Abraham i Dawid.

Dziedziczony wstyd Jezusa, będący rezultatem pochodzenia ze społecznych nizin, jest wymazywany poprzez wyjątkowy honor, który przysługuje Mu przez fakt posiadania za przodka patriarchy Abrahama, będącego fundamentem tożsamości i wiary biblijnego Izraela. Jezus jako potomek Abrahama dziedziczy jego cnoty, tak bardzo cenione w tradycji Starego Testamentu: wiarę (Rdz 15) oraz posłuszeństwo Bogu (Rdz 22). Te wartości niejako wynoszą Go na sam szczyt społecznej drabiny i całkowicie zmazują wstyd wynikający z niskiego pochodzenia.

Mateusz ukazuje również Jezusa jako pochodzącego z najbardziej czcigodnego spośród dwunastu plemion, stanowiących fundament narodu Bożego wybrania, mianowicie plemienia Judy, w którym najbardziej godną czci postacią był Dawid - założyciel królewskiej dynastii. Jezus jako potomek Dawida dziedziczy po nim honor przynależny wszystkim potomkom tego czcigodnego protoplasty - jest to honor królewski. Dzięki tej strategii pragmatycznej zastosowanej przez Mateusza w rodowodzie Jezusa (1,1-17), nie ma On być postrzegany przez czytelnika dalszej narracji jego Ewangelii jako pochodzący ze społecznych nizin galilejski wieśniak, lecz jako ktoś w kogo żyłach płynie królewska krew. Wstyd niskiego urodzenia jest tu całkowicie zakryty przez królewskie pochodzenie.

\subsection{Konfrontacje Jezusa $\mathrm{z}$ faryzeuszami i uczonymi w Piśmie jako próby pohańbienia/zawstydzenia Go (Mk 11 -12)}

Narracje wszystkich czterech Ewangelii są przesiąknięte opowiadaniami o konfrontacjach Jezusa $\mathrm{z}$ religijnymi żydowskimi autorytetami, które podejmują działania, by publicznie pohańbić Go, pozbawiając szacunku w oczach tłumu. Konfrontacje te mają dosyć zestandaryzowany przebieg. Odbywają się według mechanizmu tzw. gry o honor, realizowanej w oparciu o wspomnianą wyżej zasadę „wyznanie - odpowiedź". Mechanizm ów zawiera cztery sukcesywne etapy: publiczne wyzwanie honoru, podjęcie wyzwania, odpowiedź/ 
riposta, werdykt publiczności ${ }^{11}$. Prześledzimy skrótowo w jaki sposób religijni przywódcy Izraela dążyli do okrycia Jezusa publicznym wstydem w Mk 11-12, skupiając się szczególnie na perykopie Mk 11,27-33'12.

Należy tu jeszcze przypomnieć, że do gry o honor przystępować mogli jedynie ludzie pochodzący z tych samych lub sąsiednich warstw społecznych. Jeżeli zatem arystokracja żydowska - do której bez wątpienia należy zaliczyć faryzeuszów, uczonych w Piśmie i saduceuszów - rzuca Jezusowi wyzwanie o honor, a nie ignoruje Go jako bezwartościowego człowieka ze społecznych nizin, to znaczy, że ludzie ci uznają, iż Jezus posiada porównywalną do ich własnej społeczną wartość, której chcą Go pozbawić, rzucając Mu wyzwanie w grze honor.

Akcja opowiadań zawartych w Mk 11-12 rozpoczyna się narracją o wjeździe Jezusa na osiołku do świętego miasta Jerozolimy i rozgrywa się w tym mieście podczas dorocznych obchodów Paschy. Już sam uroczysty wjazd Jezusa do Jerozolimy na osiołku (Mk 11,1-11) jest zrelacjonowany przez Marka w taki sposób, by wywołać intertekstualne echa z Za 9,913 i Ps 118,25n, nadając w ten sposób temu wydarzeniu koloryt mesjański i królewski i przez to eksponując wyjątkową godność Jezusa, której żydowska religijna arystokracja starać się będzie Go pozbawić.

Jednym z miejsc konfrontacji Jezusa z oponentami w Mk 11-12 jest jerozolimska świątynia - centralne miejsce kultu Boga, z którego władze religijne uczyniły targowisko. Jezusowy czyn wypędzenia przekupniów z dziedzińca pogan w jerozolimskiej świątyni (Mk 11,15-18) był jedną z przyczyn gry o honor, którą podjęli z Nim

${ }^{11}$ Zob. Z. C r o o k, Honor, Shame, and Social Status Revisited, "Journal of Biblical Literature", 3(2009), s. 591-611.

12 Konfrontacja, która opowiedziana jest w perykopie Mk 11,27-33 rozpoczyna sekwencję zdarzeń prowadzących do Jego męki, śmierci i zmartwychwstania. Zob. R.T. F r a n c e, The Gospel of Mark. A Commentary on the Greek Text, Grand Rapids 2002, s. 453-454.

13 Relacje intertekstualne pomiędzy Za 9,9 a NT kompetentnie ukazuje: A. K u b i ś, The Book of Zechariah in the Gospel of John, Gabalda, Pendé 2012, s. 27-114. 
żydowscy religijni arystokraci: „Przyszli znowu do Jerozolimy. Kiedy chodził po świątyni, przystąpili do Niego arcykapłani, uczeni w Piśmie i starsi i zapytali Go: «Jakim prawem to czynisz? I kto ci dał tę władzę, żebyś to czynił?»” (Mk 11,27-28). Słowa te są publicznym wyzwaniem skierowanym do Jezusa, którego stawką jest pozbawienie Go honoru, czyli publiczne zawstydzenie. Ich pytanie zmierza do wykazania Mu, że nie miał prawa wypędzać przekupniów ze świątyni, gdyż władzę sprawuje w niej arcykapłan i podlegli mu ludzie. W pytaniu: „Kto ci dał tę władzę, żebyś to czynił?”, użyte zostało przez nich greckie słowo eksousia, które oznacza w obecnym kontekście autorytet, z mocy którego Jezus dokonywał owego haniebnego w ich mniemaniu czynu, będącego powodem podjętej już uprzednio decyzji o zabiciu Go $(\mathrm{Mk} 11,18)^{14}$.

Jezus, wypędzając przekupniów ze świątyni (Mk 11,15-19), powoływał się na autorytet Boga, gdyż czynowi temu towarzyszyły wypowiadane przez Niego słowa ze świętych ksiąg: „Czyż nie jest napisane: «Mój dom ma być domem modlitwy dla wszystkich narodów, lecz wy uczyniliście go jaskinią zbójców»" (zob. Iz 56,7; Jr 7,11). Powoływał się zatem na autorytet (eksousia) Boga, z którego polecenia oczyszcza jerozolimską świątynię z niewłaściwych praktyk. Ów Boży znak jest odczytany przez religijne autorytety judaizmu, jako czyn uzurpatora, który zagraża ich statusowi. Jako że ten czyn Jezusa oraz liczne uzdrowienia i inne cuda, które go poprzedzały, zjednywały Mu tłumy idących za Nim fascynatów, Jego oponenci podjęli decyzję o zgładzeniu Go: „Kiedy doszło to do arcykapłanów i uczonych w Piśmie, szukali sposobu, jak by Go zgładzić. Czuli bowiem lęk przed Nim, gdyż cały tłum był zachwycony jego nauką" (Mk 11, 18). Wyzwanie do gry o honor, które religijne żydowskie autorytety kierują do Jezusa w Mk 11, 27-33, należy widzieć na tym właśnie tle. Ich pytania «Jakim prawem to czynisz? I kto ci dał tę władzę, żebyś to czynił?» (Mk 11, 28) mają wyraźnie na celu pozbawienie Go Bożego autorytetu, na który się powołuje i zawstydzenie

14 Więcej na temat znaczenia tego rzeczownika w Mk zob. J. K r ę c i d ł o, Honor $i$ wstyd w interpretacji Ewangelii, dz. cyt., s. 219. 
Go wobec zgromadzonego w świątyni tłumu, po to, by móc następnie podjąć bardziej zdecydowane działania zmierzające do unicestwienia Go (zob. Mk 11,18).

Jezus podejmuje publiczną grę o swój honor, do której wezwali Go arcykapłani, uczeni i starsi w jerozolimskiej świątyni. Nie daje im jednak prostej odpowiedzi na postawione pytanie o autorytet, z którego mocy działa, lecz ripostuje pytaniem: „Zadam wam jedno pytanie. Odpowiedzcie Mi na nie, a powiem wam, jakim prawem to czynię. Czy chrzest Janowy pochodzi z nieba, czy też od ludzi?" (Mk 11,30). Tym pytaniem Jezus rzuca wyzwanie o honor swoim oponentom. Jego pytanie staje się dla nich bardzo kłopotliwe, gdyż mają oni świadomość, że jakąkolwiek odpowiedź dadzą, staną na straconej pozycji wobec arbitrażu - przysłuchującego się tej konfrontacji - tłumu. Jeżeli uznaliby, że chrzest Janowy pochodzi z nieba, to naraziliby się na zarzut: „Dlaczego więc nie uwierzyliście mu?” (Mk 11,31). Jeżeli zaś odpowiedzieliby, że chrzest ten pochodzi od ludzi, to wystawiliby się na niełaskę tłumu, gdyż Jan powszechnie był uważaniu za proroka (Mk 11,32). Nie potrafią zatem dać odpowiedzi, która w oczach słuchaczy (i czytelników Ewangelii) dawałaby im przewagę nad Jezusem w prowadzonej grze o honor, którą sami zainicjowali. Odpowiadając: „Nie wiemy” ( Mk 11,33), wychodzą $\mathrm{z}$ tej gry jako przegrani - w arbitrażowej ocenie tłumu okrywają się wstydem, a Jezus nabywa ich kosztem dodatkowy honor (będący przypomnijmy - dobrem limitowanym) ${ }^{15}$.

\subsection{Wstyd/hańba śmierci krzyżowej Jezusa przezwyciężona ukazaniem procesu ukrzyżowania jako Jego honorowego wywyższenia (J 18 - 19)}

Ewangelista Jan opowiada o wydarzeniach od pojmania Jezusa w Ogrodzie Getsemani po Jego okrutną śmierć na krzyżu w taki

15 Por. J. H. He 11 e r m a n, Challenging the Authority of Jesus: Mark 11:27-33 and Mediterranean Notions of Honor and Shame, "Journal of the Evangelical Theological Society", (2000) 43/2, s. 224. 
sposób, by w umysłach czytelników przełamać kulturowy stereotyp hańby krzyża. Śmierć krzyżowa była bowiem powszechnie postrzegana jako najbardziej haniebny i wstydliwy rodzaj kary, przeznaczony dla ludzi, których chciano maksymalnie udręczyć fizycznie i pozbawić godności w oczach społeczeństwa. Autor Czwartej Ewangelii podejmuje starania, by haniebne wydarzenie śmierci krzyżowej Jezusa przedstawić w taki sposób, aby czytelnicy dostrzegli w tym wydarzeniu etapy Jego wywyższenia i pozyskiwania honoru przy jednoczesnym traceniu honoru (czyli hańbie, wstydzie) przez sprawców tej okrutnej zbrodni. Prześledzimy obecnie opowiadanie J 18-19, ukazując w jaki sposób autor realizuje ową strategię pragmatyczną.

W J 18-19 z łatwością można zauważyć takie porządkowanie materiału przez autora, by wyeksponować obecność sekwencji formalnych elementów strukturalnych dwóch rzeczywistości: królewskiej konsekracji i rzymskiego przewodu sądowego.

Dążność do ukazania krzyżowej śmierci Jezusa jako intronizacji królewskiej uwidacznia się już w finezyjnej strukturze tego opowiadania. J 18-19 ma bowiem strukturę koncentryczną (ABCB'A') ${ }^{16}$, w której centrum znajduje się perykopa C: 18,28 - 19,16a, eksponująca królewską tożsamość Jezusa jako tego, którego królestwo nie jest z tego świata. Jest to ujęcie paradoksalne, wręcz szokujące: Ten, którego, według ludzkich kryteriów pozbawia się honoru, okrywając największą z możliwych hańbą i wstydem, poprzez ukrzyżowanie jako złoczyńcę i zbrodniarza, posiada w istocie królewską i Boską tożsamość, z którą wiąże się wyjątkowa godność i honor. Ta prawda stoi w centrum pragmatycznej argumentacji autora Czwartej Ewangelii. W jaki sposób Jan przekonuje czytelnika rozdziałów 18-19 do uwierzenia w królewską tożsamość Jezusa? Otóż wszystkie poszczególne etapy pozbawiania Jezusa życia i honoru - począwszy od pojmania do złożenia w grobie są ukazane jako etapy Jego królewskiej konsekracji. Zwróćmy tu uwagę tylko na trzy kluczowe momenty.

${ }_{16}$ Zob. F. J. M o lo n e y, The Gospel of John, Collegeville 1998, s. 482. Zob. też: I. de la P o t t e r i e, Męka Jezusa Chrystusa wedtug Ewangelii Jana, Kraków 2006, s. 37. 
Podczas pojmania w Getsemani, gdy Jezus ujawnia swoją tożsamość kohorcie rzymskich żołnierzy oraz sługom arcykapłanów, którzy przyszli Go aresztować, mówiąc dwukrotnie „Ja jestem” (18,5-6) ${ }^{17}$, ludzie ci upadają na ziemię. Gest ten należy interpretować jako symboliczne oddanie Mu szczególnego honoru ${ }^{18}$.

Drugi kluczowy element ukazywania procesu i śmierci krzyżowej Jezusa jako królewskiej konsekracji, to Jego dialog z Piłatem. Na jego pytanie: „Czy ty jesteś królem żydowskim?” (J 18, 33), Jezus odpowiada: „Królestwo moje nie jest z tego świata” (J 18,3 6). Piłat kontynuuje: „A więc jesteś królem?”, a Jezus potwierdza: „Tak, jestem królem" (J 18, 37). Szczyt finezji w eksponowaniu królewskiego honoru Jezusa osiąga autor w perykopie J 19,13-16, gdzie mowa jest o tym, że Piłat, po przesłuchaniu Jezusa, wyprowadził Go na zewnątrz i zasiadłszy na trybunale $(\mathrm{J} 19,13)$ wypowiedział finalną sentencję: „Oto wasz król!” (J 19, 14). Użyty w J 19, 13 grecki czasownik ekathisen określający czynność Piłata może być interpretowany zarówno w sensie intranzytywnym jak i tranzytywnym, tzn. całą wypowiedź można rozumieć zarówno jako siadanie przez niego na sędziowskim trybunale jak i sadzanie Jezusa na tym trybunale ${ }^{19}$. Owa dwuznaczność wydaje się być zamierzona: mamy tu zatem jednocześnie świadectwo wypowiedziane przez rzymskiego urzędnika odnośnie do królewskiej godności Jezusa, jak i potraktowanie Go po królewsku poprzez posadzenie na trybunale.

Trzeci ważny sygnał odnośnie do królewskiej godności Jezusa daje Jan w narracji o pochówku Jego ciała w grobie w ogrodzie (J 19, 38-42). Ukrzyżowanego ciała Jezusa nie wrzucono do zbiorowej mogiły zgodnie z przyjętą praktyką traktowania ciał ludzi, którzy byli krzyżowani, lecz urządzono mu honorowy, wręcz królewski pogrzeb.

${ }_{17}$ Mamy tu do czynienia z formułą samoobjawieniową. Zob. C. S. K e e n e r, The Gospel of John. A Commentary, t. 2, Peabody 2002, s. 1081-1082.

${ }_{18}$ Zob. F. J. M o lo n e y, The Gospel of John, dz. cyt., s. 485.

19 R. E. B row n, The Gospel according to John, t. 2, New York 1970, s. 881. Szerszą argumentację przedstawia: J. H. N e y r e y, Jesus the Judge. Forensic Process in John 18:21-59, "Biblica”, 68(1987), s. 509-542. 
Autor przekonuje o tym czytelnika poprzez wzmiankę, że faryzeusz Nikodem przyniósł sto funtów mieszaniny mirry i aloesu (ok. 32,5 kilograma) po to, by namaścić ciało Jezusa przed złożeniem Go do grobu $^{20}$. Mieszanka tych substancji stosowana była przy pogrzebach członków rodzin królewskich. Jej ilość natomiast znacznie przewyższa tę, która potrzebna była do pochówku jednego człowieka. Mamy tutaj zatem wyraźnie do czynienia $\mathrm{z}$ hiperbolą, mającą za zadanie podkreślić królewską godność Jezusa - został On namaszczony na Króla. Krzyż stał się Jego zwycięskim tronem. Narzędzie hańby i powód do najgłębszego wstydu i poniżenia nie umniejszyło Jego królewskiego i Boskiego statusu.

Drugim sposobem „przekuwania” hańby krzyżowej śmierci Jezusa w Jego wywyższenie jest takie porządkowanie poszczególnych elementów narracji J 18-19, by czytelnik dostrzegł w nich sekwencję elementów strukturalnych rzymskiego procesu sądowego ${ }^{21}$. Są to następujące elementy: aresztowanie Jezusa (J 18,4-11), oskarżenia (J 18, 29-32), przesłuchanie/cognitio (J 18, 33-37), werdykt (J 18, 38-40), ostrzeżenie (J 19, 1-3), oskarżenia (J 19, 4-8), przesłuchanie/cognitio (J 19, 9-12), werdykt (J 19, 13-15), sentencja/kara (J 19, 16). Występują tutaj zatem dwa cykle procesu sądowego Jezusa, prowadzonego zgodnie z rzymskimi standardami. Pomimo wyroku uniewinniającego ogłoszonego przez Piłata: ,Ja nie znajduję w nim żadnej winy” (J 18, 38) oraz ogłoszenia Jezusa królem: „Oto wasz król!” (J 19, 14) Jezus został niesprawiedliwie skazany na haniebną karę śmierci przez ukrzyżowanie. Zarówno żydowscy oskarżyciele Jezusa, którzy wymusili na Piłacie ów haniebny wyrok, jak i on sam, reprezentujący etos rzymskiego urzędnika, tracą w ten sposób honor, ściągając na siebie najwyższą hańbę i wstyd. Jezus zaś i ci spośród czytelników, którzy się z Nim identyfikują stają się uczestnikami Bożego zwycięstwa i partycypują w Jego wywyższeniu/honorze.

${ }^{20}$ Szczegółową analizę egzegetyczną tej perykopy znaleźć można np. w komentarzu: R. E. B r o w n, The Gospel according to John, dz. cyt., s. 940-941.

${ }^{21}$ Zob. B. J. M a 1 i n a, R. L. R o h r b a u g h, Social-Science Commentary on the Gospel of John, Minneapolis 1998, s. 249. 


\section{PODSUMOWANIE}

W niniejszym artykule postawiliśmy sobie zadanie pokazania, w jaki sposób rozumiano wstyd w starożytnej cywilizacji śródziemnomorskiej oraz ukazania na kilku przykładach implikacji tego faktu dla właściwego odczytania i interpretacji ksiąg Nowego Testamentu. Jako że kategoria wstydu była postrzegana w kulturze śródziemnomorskiej owego czasu inaczej niż w obecnej zachodniej cywilizacji, w pierwszej części artykułu ukazane zostało powiązanie wstydu $\mathrm{z}$ honorem jako najbardziej cenioną wartością w społecznościach owej cywilizacji. Wstyd, stanowiący w tamtej kulturze antytezę honoru, rozumiany był jako antywartość: niesława, niegodność, hańba, zła reputacja itp. Nie był on postrzegany przede wszystkim jako kategoria etyczna, definiująca wewnętrzną wartość człowieka, lecz jako brak honoru w jego publicznej ocenie. Ludzie przychodzący na świat w rodzinach o niższym statusie społecznym dziedziczyli niższy honor, a zatem ciążył na nich większy wstyd. Każdy mężczyzna był zobowiązany do codziennego podejmowania walki o honor, który mógł pozyskać dla siebie i rodziny poprzez konfrontacje według reguł tzw. gry o honor oraz przez pełnienie dzieł dobroczynnych.

Wydarzenia opowiedziane na kartach Nowego Testamentu odwołują się do myślenia w kategoriach honoru i wstydu, dlatego też w interpretacji biblijnych perykop należy to zagadnienie brać pod uwagę. $\mathrm{W}$ artykule ukazaliśmy implikacje tego typu myślenia na przykładzie trzech wybranych fragmentów Nowego Testamentu: rodowodu Jezusa w Mt 1,1-17, Jego konfrontacji z faryzeuszami i uczonymi w Piśmie w Mk 11-12 oraz Janowego opowiadania o męce, krzyżowej śmierci i pochówku Jezusa (J 18-19). W każdej z tych perykop autorzy odwołują się do myślenia adresatów w kategoriach honoru i wstydu, ukazując Jezusa jako ucieleśnienie honoru, tych zaś, którzy próbują Go pohańbić w oczach innych jako zasługujących na wstyd. 


\section{Anthropological Notion of Shame and Its Impact for New Testament Interpretation Summary}

The article aims at exploring the anthropological notion of shame in the circum-Mediterranean culture and at showing its impact on the interpretation of the New Testament. Shame in this culture was not perceived - like today - as a kind of negative emotion but as social anti-value, the antonym of honor. Depending on the social status of a family in which one was born, he or she participated in honor or shame of relatives. Every man was obliged to acquire each day honor for himself and his family. Honor being a limited good could be lost. Loosing honor meant that the whole family, real or fictive, ran into shame. Examining three passages from the New Testament, namely Jesus genealogy (Matt. 1:1-17), his confrontations with Pharisees and Scribes narrated in Mark 11 - 12, and passion narrative according to John $18-19$, the author of the article shows the impact of honor and shame culture for proper understanding of the message of the New Testament.

Słowa klucze: honor i wstyd, antropologia kulturowa, Mt 1,1-17, Mk 11-12, J 18-19

Key words: honor and shame, social-scientific approach, Matthew 1,1-17, Mark 1112, John 18-19

Nota o autorze: ks. prof. dr hab. Janusz Kręcidło MS - kierownik Katedry Historii Biblijnej Wydziału Teologicznego UKSW; obszary badań: Nowy Testament, historia i metodologia biblijna, socjologia i antropologia kulturowa.

\section{Bibliografia}

Arystoteles, Etyka nikomachejska, (tłum. D. Gromska), Warszawa 2007.

Brown R. E., The Gospel according to John, t. 2, New York 1970.

Crook Z., Honor, Shame, and Social Status Revisited, "Journal of Biblical Literature", 3(2009), s. 591-611.

Dodziuk A., Wstyd. Jak lepiej go rozumieć i nie pozwolić, żeby zatruwat nam życie?, Warszawa 1999.

France R.T., The Gospel of Mark. A Commentary on the Greek Text, Grand Rapids 2002.

Hellerman J. H., Challenging the Authority of Jesus: Mark 11:27-33 and Mediterranean Notions of Honor and Shame, "Journal of the Evangelical Theological Society", (2000) 43/2, s. 224. 
Keener C. S., The Gospel of John. A Commentary, t. 2, Peabody 2002.

Kręcidło J., Honor $i$ wstyd w interpretacji Ewangelii. Szkice z egzegezy antropologicznokulturowej, Warszawa 2013.

Kubiś A., The Book of Zechariah in the Gospel of John, Gabalda, Pendé 2012.

Malina B. J., Rohrbaugh R. L., Social-Science Commentary on the Gospel of John, Minneapolis 1998.

Malina B. J., The New Testament World. Insights from Cultural Anthropology, Louisville 2001.

Moloney F. J., The Gospel of John, Collegeville 1998.

Neyrey J. H., Jesus the Judge. Forensic Process in John 18:21-59, “Biblica”, 68(1987), s. 509-542.

Plutarch, Moralia. Wybór pism filozoficzno-moralnych, (tłum. Z. Abramowiczówna), Wrocław 2005.

Potterie I. de la, Męka Jezusa Chrystusa wedtug Ewangelii Jana, Kraków 2006.

Rohrbaugh R. L., Honor. Core Value in the Biblical World, w: D. Neufeld, R. E. DeMaris (red.), Understanding the Social World of the New Testament, London 2010. 